\title{
Sikap penonton terhadap film nasionalisme (Jenderal Soedirman)
}

\author{
Bramedia Ridho Satria $^{1}$ dan Rizky Rinaldy ${ }^{2}$ \\ 1,2Sekolah Tinggi Ilmu Komunikasi LSPR, Jakarta, Indonesia
}

\begin{abstract}
ABSTRAK
Artikel ini membahas sikap penonton terhadap Film Nasionalisme Jenderal Soedirman. Adapun tujuan dari penelitian ini, untuk mengetahui sikap Mahasiswa Universitas Moestopo mengenai Film Jenderal Soedirman. Teori yang digunakan dalam penelitian ini yaitu teori sikap, kegunaan dan gratifikasi, dan efek komunikasi massa. Teori efek komunikasi massa terbagi menjadi dua dimensi yakni dimensi kognitif dan dimensi afektif, yang setelahnya dioperasionalisasikan menjadi 18 pernyataan kuisioner penelitian. Penelitian ini menggunakan metode penelitian kuantitatif deskriptif untuk mendapatkan gambaran detail mengenai suatu gejala atau fenomena. Teknik pengumpulan data dilakukan dengan cara memberikan kuesioner terhadap responden. Angket yang digunakan dalam penelitian ini merupakan angket tertutup yang telah disediakan jawabannya sehingga responden tinggal memilih satu jawaban yang sesuai dengan pilihan mereka. Subjek penelitian melibatkan mahasiswa fakultas Ilmu Komunikasi Universitas Prof. Dr. Moestopo (Beragama) yang dijadikan responden penelitian. Populasi penelitian ini sebesar 362 orang dan diperoleh sampel sebanyak 78 orang dan teknik yang digunakan adalah teknik nonprobability sampling dan purposive sampling, artinya peneliti mengambil sampel dengan kriteria tertentu yang sudah menonton film Jenderal Soedirman. Dapat disimpulkan, bahwa Hasil dari dimensi kognitif sebesar 3.89 dan dimensi afektif sebesar 3.88 dapat dilihat dari penjelasan deskriptif statistik per dimensi dan dapat di simpulkan bahwa mayoritas responden setuju bahwa film Jenderal Soedirman mampu memberikan informasi, pemahaman baru dan memberikan perasaan emosional tentang sikap nasionalisme.
\end{abstract}

Kata-kata Kunci: Film; sikap penonton; nasionalisme; kuantitatif; deskriptif

\section{Attitude of audience towards nationalism film (Jenderal Soedirman)}

\begin{abstract}
This article is about the attitudes of the audience towards Nationalism in the film Jenderal Soedirman. The purpose of this research is to know the attitudes of students at the University of Prof. Dr. Moestopo. Theories used in this research are attitude theory, usability and gratification, and the effect of mass communication. The theory of the effects of mass communication is divided into two dimensions namely the cognitive dimension and the affective dimension, which afterward are operationalized into 18 research questionnaire statements. This study uses descriptive quantitative research methods to get a detailed picture of a symptom or phenomenon. Data collection techniques are carried out by giving questionnaires to respondents. The questionnaire used in this study is a closed questionnaire whose answers have been provided so that respondents only need to choose one answer that is following their choice. The research subjects involved students of the Faculty of Communication, University of Prof. Dr. Moestopo (Religion) is used as a research respondent. The population of this study was 362 people and obtained a sample of 78 people and the technique used was nonprobability sampling and purposive sampling techniques, meaning researchers took samples with certain criteria who had watched the film General Soedirman. It can be concluded, that the results of the cognitive dimension of 3.89 and the affective dimension of 3.88 can be seen from the descriptive explanation of statistics per dimension and it can be concluded that the majority of respondents agree that the film General Soedirman is able to provide information, new understanding and provide emotional feelings about attitudes of nationalism.
\end{abstract}

Keywords: Film; nationalism; the attitudes of audience; quantitative; descriptives

Korespondensi: Bramedia Ridho Satria, S.I.Kom. STIKOM the London School of Public Relations. Jl. K.H Mas Mansyur, Kav. 35, Jakarta Pusat 10220.Email: bramediaridho@gmail.com 


\section{PENDAHULUAN}

Sebagai makhluk sosial, manusia setiap harinya melakukan komunikasi untuk mendapatkan informasi. Seiring perkembangan teknologi komunikasi yang semakin maju ini telah memberikan kemudahan kepada manusia untuk memenuhi kebutuhan sehari - harinya, seperti kebutuhan pendidikan, hiburan, bahkan informasi.

Dalam perkembangannya, sebagai suatu ilmu, komunikasi telah melahirkan apa yang disebut dengan komunikasi massa yang tentu saja membutuhkan bantuan media massa dalam proses penyampaian pesan dari komunikator kepada komunikan. Media massa modern yang kita ketahui saat ini terbagi ke dalam lima jenis, yaitu 1) Surat Kabar/Pers, 2) Radio, 3) Televisi, 4) Film, dan 5) Internet. Bahkan di negara adidaya seperti Amerika Serikat saat ini buku telah dikatagorikan sebagai media massa (Abidin, 2017).

Film adalah media yang menyampaikan topik atau pesan secara luas namun ringan sehingga mudah dipahami oleh penonton. Film merupakan media yang memiliki daya jangkau sangat luas, bahkan film bisa diakses hampir di seluruh dunia dan pada waktu yang bersamaan (Sutorini, 2019)

Dengan berkembangnya jenis-jenis film, berkembang nya juga fungsi dan manfaat film, sebagai contoh film yang berfungsi sebagai media hiburan. Namun, di dalam fungsi film sendiri juga memiliki nilai informatif, edukatif, dan persuasif. Jika dibandingkan dengan media konvensional, film memiliki karakteristik yang sangat berbeda dalam menyampaikan pesan komunikasi (Trianton, 2013).

The Great Train Robbery merupakan film pertama kali yang dibuat pada tahun 1903 . Namun sebelum munculnya film tersebut, ada beberapa film sederhana yang muncul di dunia. Pada tanggal 28 Desember 1895 film yang berjudul Workes Leaving the Lumiere's Factory merupakan film berdurasi sangat pendek (Sadewa, 2011). Dalam perfilman di Indonesia, Film cerita pertama yang diproduksi tepatnya di Bandung, baru ada pada tahun 1926. Film ini berjudul Loetoeng Kasaroeng (Mubasyaroh,
2014).

Berkembangnya industri film yang dimiliki Indonesia, berkembangnya juga genre-genre yang ada seperti film bergenre komedi, politik, drama, musikal, hingga bertemakan Nasionalis. Di Indonesia banyak dari masyarakat yang melupakan nilai - nilai sejarah Negaranya sendiri. Tujuan dari film nasionalis sendiri untuk meningkatkan dan menanamkan sikap pikiran dan perasaan penonton untuk menyatakan keterikatan hubungan emosional dengan Bangsa dan Negara nya.

Pada beberapa tahun yang lalu banyak sekali film - film bertema horor yang mengedepankan segi komersial, Hal tersebut membuat film film yang memiliki nilai edukasi maupun film yang memiliki kualitas yang baik jarang sekali ditemui khusunya film bertema nasionalisme. Sepanjang tahun 2000-an, ada beberapa film yang memang dibuat untuk mengangkat sisi lain kehidupan masyarakat Indonesia, tidak hanya menyajikan tayangan sebagai hiburan semata, namun juga pandangan dan ajaran mengenai nasionalisme (Natalia, 2015).

Tidak banyak sutradara yang membuat film nasionalisme, namun beberapa film nasionalisme mampu bersaing dengan film film dengan genre umum yang ada di Indonesia. Film nasionalisme yang mampu bersaing, seperti Soekarno, Habbie dan Ainun, Gie dan $5 \mathrm{~cm}$. Film - film ini berhasil membuat para penonton semakin tergerak dan memahami Nasionalisme.

Film "Jenderal Soedirman" merupakan film biopic kisah dari seorang tokoh pahlawan Indonesia. Film ini di bintangi oleh Adipati Dolken sebagai Jendral Soedirman, beberapa actor terkenal seperti Lukman Sardi, Baim Wong, dan Mathias Muchus (Dory, 2015).

Jenderal Soedirman merupakan salah seorang pejuang kemerdekaan dan bapak Tentara Nasional Indonesia. Oleh pemerintah Repubik Indonesia, Soedirman dianugerahi gelar pahlawan kemerdekaan nasional. Sekalipun secara formal dia bukan lulusan Akademi Militer, namun karena bakat, semangat dan disiplin yang tinggi serta rasa tanggungjawab dan panggilan hati nurani untuk berjuang mencapai dan menegakkan kemerdekaan Indonesia, maka dia 
cepat mencuat sebagai pemimpin di lingkungan Angkatan Perang Republik Indonesia Adi Cita Karya dalam (Ayuningtya, 2016).

Film Jenderal Soedirman bercerita tentang penghianatan Belanda yang menyatakan secara sepihak sudah tidak terikat dengan perjanjian Renville, sekaligus menghentikan gencatan senjata atau perdamaian yang telah disepakati sebelumnya. Pada tanggal 19 Desember 1948, Jenderal Simon Hendrik Spoor Panglima Tentara Belanda memimpin Agresi militer ke II menyerang Yogyakarta yang saat itu menjadi Ibukota Republik Indonesia.

Soekarno dan Hatta ditangkap dan diasingkan ke pulau Bangka. Jenderal Soedirman yang sedang didera sakit berat melakukan perjalanan ke arah selatan dan memimpin perang gerilya selama tujuh bulan. Belanda menyatakan Indonesia sudah tidak ada. Dari kedalaman hutan, Jenderal Soedirman menyiarkan bahwa republik Indonesia masih ada, kokoh berdiri bersama Tentara Nasionalisnya yang kuat. Ia berhasil membuat Jawa menjadi medan perang gerilya yang luar, membuat Belanda kehabisan logistik dan waktu. Akhinya TNI dan rakyat yang memenangkan perang. Dengan ditanda tangani pernjanjian Roem - Royen, kerajaan Belanda mengakui kedaulatan Republik Indonesia seutuhnya (Dory, 2015).

Film ini ditayangkan serentak di seluruh bioskop Indonesia pada tanggal 27 agustus
2015. Tiket film perdana "Jenderal Soedirman" menurut data terakhir yang di rilis Badan Perfilman Indonesia selama periode 27-31 Agustus 2015 sukses terjual sebanyak 74.963 lembar tiket. Sementara dari www.bintang.com total penjualan tiket telah mencapai 152.452 penonton (Djaya, 2015).

Sebuah film disadari atau tidak, dapat mengubah pola kehidupan seseorang. Terkadang ada seseorang yang ingin meniru kehidupan yang di kisahkan dalam film. Para penonton kerap menyamakan seluruh pribadinya dengan salah seorang pemeran film (Akbar, 2017).

Film nasionalisme memang cukup banyak, hal tersebut bertujuan untuk memberikan nilai-nilai edukasi kepada masyarakat untuk mengenal sejarah dan tentunya memiliki sikap nasionalis. Pada tahun 2015 Film Jenderal Soerdiman berhasil masuk dalam 10 besar dalam perolehan jumlah penonton. film yang Jenderal Soedirman berhasil menarik perhatian masyarakat untuk menonton kisah seorang pahlawan yang berjuang demi kemerdekaan Republik Indonesia.

Dari latar belakang di atas peneliti akhirnya melakukan studi di Universitas Prof. Dr. Moestopo (Beragama) dengan judul penelitian "Sikap Penonton Terhadap Film Nasionalisme: Studi Deskriptif Mahasiswa Prof. Dr. Moestopo (beragama) Fakultas ilmu Komunikasi Mengenai Film Jenderal Soedirman".

Tabel 1 Jumlah Penonton Bulan September Tahun 2015

\begin{tabular}{cccc}
\hline Judul Film & Tanggal Rilis & Lama Tayang & Jumlah Penonton \\
\hline Move On & 3 September 2015 & 1 Minggu & 9.510 \\
Lily Bunga Terakhirku & 3 September 2015 & 1 Minggu & 8.000 \\
Alpha Project Arwah Penasaran & 3 September 2015 & 1 Minggu & 5.007 \\
Gangster & 27 Agustus 2015 & 2 Minggu & 199.290 \\
Jenderal Soedirman & 27 Agustus 2015 & 2 Minggu & 152.425 \\
\hline
\end{tabular}




\section{METODE PENELITIAN}

Metode penelitian yang digunakan bersifat kuantitatif deskriptif. Menurut Sugiyono dalam (Pradana, 2016) penelitian desktiptif adalah sebuah penelitian yang bertujuan untuk memberikan atau menjabarkan suatu keadaan atau fenomena yang terjadi saat ini dengan menggunakan prosedur ilmiah untuk menjawab masalah secara aktual.

Populasi menurut Sugiyono dalam (Akbar, 2017) merupakan bukan sekedar jumlah yang ada pada subyek atau obyek yang dipelajari, akan tetapi meliputi seluruh karakiteristik yang dimiliki subyek atau obyek tersebut. Pada penelitian ini, mahasiswa-mahasiswi Fakultas Ilmu Komunikasi Prof.dr. Moestopo(Beragama) Jakarta, J1. Hang Lekir Senayan Jakarta Pusat merupakan populasi yang diharapkan dapat memberikan presepsi efek komunikasi mengenai bagaimana sikap penonton terhadap film yang bertema nasionalisme. Jika menurut kriteria-kriteria yang ditetapkan sebanyak 362 orang.

Adapun sampel menurut Sugiyono dalam (Pradana, 2016) merupakan bagian dari jumlah dan karakteristik yang dimiliki oleh populasi tersebut. Sampel pada penelitian ini atau responden yang ditemukan berjumlah 78 orang dengan menggunakan rumus Slovin. Sampel tersebut tentunya mahasiswa-mahasiswi yang telah menonton film Jenderal Soedirman.

Peneliti menggunakan teknik nonprobability sampling dan purposive sampling, artinya peneliti mengambil sampel dengan kriteria tertentu atau hanya membuat yang sudah menonton film Jenderal Soedirman. Angket yang digunakan dalam penelitian ini merupakan angket tertutup yang telah disediakan jawabannya sehingga responden tinggal memilih satu jawaban yang sesuai dengan pilihan mereka. Hal ini dimaksudkan agar responden lebih gampang dan cepat menentukan pilihan jawaban yang mereka inginkan, selain itu juga agar memudahkan dalam menganalisis data.

Skala Likert adalah skala yang digunakan untuk mengukur persepsi, sikap atau pendapat seseorang atau kelompok mengenai sebuah peristiwa atau fenomena sosial, berdasarkan definisi operasional yang telah ditetapkan oleh peneliti (Febtriko, 2018). Pada penelitian ini peneliti menggunakan skala likert untuk mengukur sikap nasionalisme terhadap film Jenderal Soedirman.

Sebelum melakukan analisis mengenai Sikap Penonton terhadap Film Jenderal Soedirman dilakukan ujivaliditas terlebih dahulu terhadap pernyataan - pernyataan tentang sikap Nasionalisme pada mahasiswa/ mahasiswi Universitas Moestopo. Jumlah sampel uji validitas sebanyak 30 orang. Hasil perhitungan di bandingkan dengan tabel $\mathrm{r}$ product Moment dengan hasil $\mathrm{r}$ hitung harus lebih besar lebih dari pada $r$ tabel. Hal ini terbukti dari nilai yang didapat setiap butir pernyataan Sikap Penonton terhadap Film Jenderal Soedirman yang memiliki hasil $r$ hitung diatas 0,361 dan 0,463 sehingga dapat dinyatakan valid.

Uji Reliabilitas dilakukan terhadap 30 orang sebagai sampel pengujian reliabilitas. Pernyataan - pernyataan yang diuji reliabilitas hanya yang telah lulus dari uji Validitas ada 16 pernyataan yang di uji reliabilitasnya.

Hasil pengujian Reliabilitas Sikap penonton terhadap Nasionalisme mengenai Film Jenderal Soedirman memiliki nilai hitung Cronbach's Alpha 0,879 untuk 16 pernyataan yang di uji dengan 30 sampel. Dapat disimpulkan, bahwa instrument yang digunakan dalam penelitian ini dapat dikatakan reliable, karna telah melebihi batas minimal uji Reliabilitas yaitu lebih besar dari pada 0,600 .

\section{HASIL DAN PEMBAHASAN}

Secord dan Backman mengemukakan bahwa sikap adalah keteraturan tertentu dalam hal perasaan (afeksi), pemikiran (kognitif) dan predisposisi tindakan (konasi) seseorang terhadap suatu aspek di lingkungan sekitarnya (Pakpahan, 2017). Sikap didefenisikan sebagai pola perilaku, tendensi atau kesiapan antisipatif, predisposisi untuk menyesuaikan diri dalam situasi sosial, atau secara sedehana, sikap merupakan respon terhadap stimuli sosial yang telah terkondisikan (Azwar, 2011).

Dalam penelitian ini, teori sikap digunakan 
untuk mengetahui bagaimana para penonton film Jenderal Soedirman dalam menangkap suatu pesan atau suatu pandangan yang membentuk cara berperilaku orang yang menonton film Jenderal Soedirman.

Menurut Notoatmodjo dalam (Ardian, 2013) ada tiga komponen yang secara bersamasama membentuk sikap yang utuh (total attitude) yaitu kognitif (cognitive), afektif (affective), dan konatif (conative). Komponen kognitif merupakan pengetahuan seseorang mengenai apa yang berlaku atau apa yang benar bagi objek sikap.

Kemudian komponen afektif lebih menyangkut pada emosional yang miliki nilai subjektif seseorang terhadap suatu objek sikap. Komponen konatif atau komponen behavioral merupakan komponen terakhir dalam struktur sikap yang menunjukan kecenderungan berperilaku yang ada dalam diri seseorang berkaitan dengan objek dari sikap itu sendiri. Sikap dapat dibentuk melalui beberapa faktor mulai dari faktor pengalaman pribadi, kebudayaan, pembentukan sikap yang terbentuk bedasarkan faktor seseorang yang berpengaruh, media massa, intitusi tertentu, dan juga faktor emosi yang ada dalam diri individu itu sendiri. (Azwar, 2011).

Dalam penelitian ini, pembentukan sikap terjadi melalui media massa mengenai sikap penonton terhadap film Jenderal Soedirman. Donald K. Robert beranggapan bahwa efek hanyalah perubahan perilaku manusia setelah diterpa pesan media massa, karena fokusnya pesan, efek harus berkaitan dengan pesan yang disampaikan media massa (Ardianto, Komala dan Karlinah, 2014).

Sebagaimana dijelaskan, Steven M. Chaffee, terdapat tiga pendekatan antara lain efek kognitif, efek afektif, dan behavioral, seperti yang dijabarkan dalam penjelasan ini (Rakhmat, 2013). Efek kognitif merupakan pengetahuan atau sebuah pandangan yang terbentuk bedasarkan adanya informasi yang diperoleh khayalak yang dapat dipahami dan memiliki kepercayaan dalam informasi tersebut.

Sedangkan efek afektif merupakan sebuah emosi yang timbul dari efek kognitif yang merubah perasaan khalayak terhadap suatu informasi. Adapun efek behavioral atau disebut juga efek konatif merupakan efek dimana adanya sebuah tindakan yang dilakukan khalayak bedasarkan efek kognitif dan efek afektif yang di peroleh dari sebuah informasi. (Ardianto, Komala dan Karlinah, 2014).

Berdasarkan penjelasan yang telah diuraikan di atas, efek dari komunikasi massa dalam penelitian ini meliputi pengetahuan, pemahaman, dan perilaku penonton terhadap film Jenderal Soedirman.

Teori Kegunaan dan Gratifikasi (Uses and Gratification Theory) ini menyatakan bahwa konsumen media mempunyai kebebasan untuk memutuskan bagaimana (lewat media mana) mereka menggunakan media dan bagaimana media itu akan berdampak pada dirinya. Teori ini juga menyatakan bahwa media dapat mempunyai pengaruh jahat dalam kehidupan. Penonton bersifat aktif yakni dapat memilih tayangan mana yang ingin mereka nikmati sesuai dengan kebutuhan mereka untuk mendapatkan kepuasan. (Amalia, 2015).

Inti dari Teori Kegunaan dan Gratifikasi menyatakan bahwa media memiliki pengaruh yang terbatas karena khalayaklah yang menentukan sendiri media apa yang akan mereka gunakan. Khalayak melihat media sebagai suatu alat untuk memenuhi kebutuhan khalayak.

Berdasarkan penjelasan yang diuraikan di atas. Pada film Jenderal Soedirman, khalayak bebas untuk menonton atau menentukan sendiri film mana yang harus mereka ikuti dan mereka tonton dalam memenuhi kebutuhan mereka sendiri.

Pada dasarnya, film merupakan kumpulan gambar yang bergerak yang berisi rekaman mengenai manusia atau benda yang direkam menggunakan kamera dan ada pula film yang berbentuk animasi seperti film kartun (Sutorini, 2019).

Menurut Trianton, film adalah hasil proses kreatif para sineas yang memadukan berbagai unsur seperti gagasan, sistem nilai, pandangan hidup, keindahan, norma, tingkah laku manusia, dan kecanggihan teknologi Trianton, 2013). Dengan demikian film tidak bebas nilai karena di dalamnya terdapat pesan yang dikembangkan 
sebagai karya kolektif. Disini film menjadi alat perantara sosial. Film merupakan media komunikasi massa yang membawa pesan yang berisi gagasan-gagasan penting yang disampaikan kepada masyarakat dalam bentuk tontonan (Trianton, 2013).

Pengertian film dijelaskan Barsam sebagai rangkaian gambaran yang berurutan yang bergerak dengan cepat dan diproyeksikan dalam layar dengan objek yang diletakkan pada posisi berurutan sehingga dapat menghasilkan efek optic pada rangkaian gambar dari objek yang bergerak tersebut (Trianton, 2013). Film juga dapat didefenisikan sebagai sebuah rangkaian foto dalam film yang diproyeksikan dengan cepat ke dalam layar oleh cahaya. Sementara itu film layar lebar diartikan sebagai film yang karena gambarnya dibuat sedemikian rupa harus diputar dan dipertunjukkan di layar yang berukuran besar.

Pada dasarnya film berfungsi sebagai hiburan. Namun didalam film juga terkandung fungsi informatif, edukatif dan persuasif. Fungsi-fungsi film akan berjalan baik, karena film memiliki karakteristik yang berbeda jika dibandingkan dengan media lain yang konvensional (Trianton, 2013).

Menurut Mulyana, pada hakekatnya film merupakan sebuah film merupakan sebuah pesan yang disampaikan oleh komunikator kepada komunikan (Mulyana, 2004). Sedangkan makna tidak terdapat pada pesan melainkan pada hasil pembacaan atau pemahaman oleh penerima pesan (Trianton, 2013).

Menurut Mcquail, fungsi dan peran film dalam masyarakat pada konteks komunikasi ada empat. Pertama, film sebagai sumber pengetahuan yang menyediakan informasi tentang peristiwa dan kondisi masyarakat dari berbagai belahan dunia. Kedua, film sebagai sarana sosialisasi dan pewarisan nilai norma dan kebudayaan. Artinya selain sebagai hiburan, secara laten film juga berpotensi menularkan nilai - nilai tertentu pada penontonya (Trianton, 2013).

Dengan demikian, efektifitas film sebagai bentuk komunikasi dapat diukur dengan berbagai cara yang berbeda - beda tergantung pada apa tujuan dari proses komunikasi itu sendiri. Termasuk bagaimana tanda dipersepsi oleh penerima atau interpreter sehingga terjadi komunikasi yang afektif (Trianton, 2013).

Dalam penjelasan yang diuraikan di atas, fungsi film pada film Jenderal Soedirman adalah film Jenderal Soedirman memberikan fungsi informasi, edukatif dan persuasif serta memberikan pemahaman baru tentang Sikap Nasionalisme kepada Mahasiswa Universitas Prof. Dr. Moestopo (Bergama).

Genre merupakan jenis-jenis yang terdapat pada film, pada dasarnya genre film terbagi menjadi beberapa jenis, tergantung karakter dan isi yang ditampilkan dalam film. Beberapa jenis film yang lain diantaranya: action, drama, comedy, sci-fiction, Epic Sejarah, horror (Trianton, 2013).

Film dibagi menjadi beberapa genre yaitu, action yang merupakan jenis film yang mengandung banyak gerakan dinamis para aktor dan aktris dalam sebagian besar adegan film, seperti halnya adegan baku tembak, perkelahian, baku tembak, ledakan, perang, dan lainnya (Akbar, 2017). Genre film adventure yang merupakan jenis film yang menitik beratkan pada sebuah alur petualangan yang sarat akan teka-teki dan tantangan dalam berbagai adegan film.

Adapun genre film bioghraphy adalah jenis film yang mengulas sejarah, perjalanan hidup atau karir seorang tokoh, ras kebudayaan ataupun kelompok.. Genre film comedy adalah jenis film yang dipenuhi oleh adegan komedi dan lelucon sebagai benang merah alur cerita ini. Genre film Crime adalah jenis film yang menampilkan skenario tentang kejahatan sebagai inti dari kedeluruhan film.

Genre film documentary adalah jenis film yang berisi tentang kejadian dan peristiwa yang terjadi secara nyata. Drama adalah jenis film yang memiliki alur cerita tertentu seperti halnya percintaan, kehidupan sosial, dan lainnya. Genre family adalah jenis film yang sangat cocok untuk dapat di saksikan bersama keluarga.

Kemudian genre film history adalah jenis film yang mengandung cerita masa lalu sesuai dengankejadian dan peristiwayang telahmenjadi sebuah sejarah. Horror adalah jenis film yang berisi kejadian mistis dan berhubungan dengan 
kejadian-kejadian yang menyeramkan sebagai nyawa dari film tersebut. Romance, adalah jenis film yang berkisah tentang percintaan. dan war adalah jenis film yang memiliki cerita atau latar belakang peperangan.

Berdasarkan penjelasan yang diuraikan diatas, film Jenderal Soedirman berada dalam genre Historical Biography karena cerita dalam film Jenderal Soedirman merupakan peristiwa Sejarah yang benar terjadi dan juga dapat digolongkan dalam genre Biografi karena secara khusus membahas tentang kehidupan Jenderal Soedirman.

Nasionalisme secara etimologi berasal dari kata "nasional" dan "isme" yaitu paham kebangsaan yang mengandung makna kesadaran dan semangat cinta tanah air, memiliki kebanggaan sebagai bangsa, atau memelihara kehormatan bangsa, memiliki rasa solidaritas terhadap musibah dan kekurang beruntungan saudara setanah air, sebangsa dan senegara serta menjunjung tinggi nilai persatuan dan kesatuan. Dari pengertian tersebut nasionalisme dapat di artikan sebagai faham tentang kebangsaan dan sikap cinta tanah air yang tinggi yang harus dimiliki oleh warga negara, merasa memiliki sejarah dan cita-cita yang sama dalam tujuan berbangsa dan bernegara. Beberapa ahli juga banyak yang mendefi- nisikan tentang konsep nasionalisme (Alfaqi, 2015).

Abdul Munir Mulkhan dalam (Alfaqi, 2015), mengatakan bahwa "nasionalisme adalah sebuah gagasan mengenai kesatuan kebangsaan dalam suatu wilayah politik kenegaraan". Kemudian menurut Perry, "Nasionalisme adalah suatu ikatan sadar yang dimiliki bersama oleh sekelompok orang yang memiliki kesamaan bahasa, kebudayaan dan sejarah yang ditandai dengan kejayaan dan penderitaan bersama dan saling terikat dalam suatu negeri tertentu" (Alfaqi, 2015). Pada dasarnya nasionalisme memang lahir dari bermacammacam cara, mulai dari karena kesamaan akan sejarah, kebudayaan, cita-cita, ketidakadilan, penindasan, serta sebagai wujud perlawanan suatu kelompok bangsa (Alfaqi, 2015).

Berdasarkan uraian penjelasan di atas, dapat disimpulkan bahwa film Jenderal Soedirman dianggap mampu membangkitkan semangat
Nasionalisme kepada penonton. Penonton sendiri merupakan orang yang menonton suatu pertunjukan seperti pertunjukan drama, bioskop dan lain sebagainya. Di dalam film, hubungan antara film dengan penonton memiliki kesamaan dengan buku dibandingkan dengan televisi (Stanley, 2011).

Menurut Kitley, penonton adalah suatu proyeksi, oleh suatu lembaga, atas keanekaragaman tanpa batas dari praktikpraktik menonton yang nyata dari individuindividu dan kelompok-kelompok (Anshari, 2014). Dapatdi simpulkan bahwa penonton adalah suatu perkumpulan atau beberapa orang yang beragam mulai dari anak - anak sampai orang tua salah satunya dalam film.

Di dalam penelitian ini, profil responden merupakan karakteristik rResponden yang terdiri dari jenis kelamin, dan usia yang disebar kepada responden sebanyak 78 orang sebagai sampel. Jenis kelamin laki - laki berjumlah 40 responden $(51.29 \%)$ dan jenis kelamin perempuan adalah 38 responden (48.71\%). Dapat disimpulkan bahwa jenis kelamin laki - laki lebih dominan menonton film Jenderal Soedirman.

Pada kelompok usia, diketahui bahwa 15 - 19 tahun 25 responden $(24.19 \%), 20-25$ tahun 52 responden $(66.66 \%)$ dan 26 - 30 tahun 1 responden (1.29\%). Jadi dapat disimpulkan, bahwa penonton film Jenderal Soedirman di Universitas Moestopo adalah yang berusia 20 - 25 tahun. Sedangkan berdasarkan domisili diketahui responden yang berasal dari kota Jakarta sebanyak 38 responden $(48.72 \%)$, kota Bogor 10 responden (12.82\%), kota Depok 5 responden $(6.41 \%)$, kota Tanggerang 11 responden (14.10\%), kota Bekasi 13 responden (16.66\%), dan di luar Jabodetabek 1 responden (1.29\%). Berdasarkan uraian diatas bahwa penyebaran film Jenderal Soedirman cukup signifikan.

Berdasarkan jawaban responden dari pernyataan menurut Anda cukup banyak Informasi tentang Jenderal Soedirman, responden yang menjawab sangat setuju dan setuju sebanyak 61 responden $(78.2 \%)$, dan yang menjawab ragu - ragu sebanyak 15 responden (19.2\%) dan sisanya sebanyak 2 
responden menjawab tidak setuju (2.6\%). Dapat disimpulkan, bahwa mayoritas menjawab setuju. Hasil perhitungan rata - rata atau Mean menunjukkan Nilai 3.871 yang berada pada zona setuju. Hasil perhitungan ini juga mengindikasikan bahwa sampel penelitian menyatakan bahwa cukup banyak mendapat informasi mengenai Jenderal Soedirman

Pada jawaban responden dari pernyataan apakah Anda cukup memahami tentang Nasionalisme, responden yang menjawab sangat setuju dan setuju sebanyak 55 responden (70.5\%), dan yang menjawab ragu - ragu 23 responden (29.5\%) dan tidak setuju, sangat tidak setuju Dapat disimpulkan, bahwa mayoritas menjawab setuju. Hasil perhitungan rata - rata atau Mean menunjukkan Nilai 3.859 yang berada pada zona setuju. Hasil perhitungan ini juga mengindikasikan, bahwa sampel penelitian menyatakan bahwa sudah cukup memahami tentang Nasionalisme.

Jawaban responden tentang apakah informasi Film jenderal Soedirman sudah cukup, responden yang menjawab sangat setuju dan setuju sebanyak 58 responden (74.3\%), dan yang menjawab ragu - ragu sebanyak 18 responden $(23.1 \%)$, sedangkan responden yang menjawab tidak setuju dan sangat setuju 2 responden $(2.6 \%)$. Diketahui nilai mean score sebesar 3.781 hasil tersebut berada pada kategori setuju karena berada pada rentang skala skala 3,4-4,2. dari hasil tersebut dapat diketahui bahwa responden cukup mengetahui informasi tentang film Jenderal Soedirman.

Berdasarkan jawaban responden tentang Apakah Film Jenderan soedirman sudah cukup meningkatkan pengetahuan Anda tentang Nilai - Nilai Nasionalisme, responden yang menjawab sangat setuju dan setuju sebanyak 62 responden (79.5\%), dan yang menjawab ragu - ragu sebanyak 15 responden (19.2\%), sedangkan responden yang menjawab sangat tidak setuju dan setuju sebanyak 1 responden $(1.3 \%)$. Diketahui nilai mean score sebesar 3.936 hasil tersebut berada pada kategori setuju karena berada pada rentang skala skala $3,4-$ 4,2. dari hasil tersebut dapat diketahui bahwa menurut responden Nilai - Nilai Nasionalisme di film Jenderal Soedirman sudah mampu meningkatkan pengetahuan Nasionalisme responden.

Adapun jawaban responden tentang sudah cukupkah Film Jenderal Soedirman memberikan contoh tentang sikap Nasionalis, responden yang menjawab sangat setuju dan setuju sebanyak 63 responden $(80.8 \%)$ dan yang menjawab ragu - ragu 15 responden (19.2\%), sedangkan yang menjawab sangat setuju dan tidak setuju 0 responden. Diketahui nilai mean score sebesar 4.039 hasil tersebut pada kategori setuju karena berada pada rentang skala skala 3,4-4,2. Dari hasil tersebut dapat diketahui, bahwa Film jenderal Soedirman memberikan contoh yang cukup bagus tentang sikap Nasionalis

Berdasarkan jawaban responden tentang setelah Anda menonton Film Jenderal Soedirman, apakah Anda merasakan adanya nasionalisme, responden yang menjawab sangat setuju dan setuju sebanyak 61 responden (78.2), dan yang menjawab ragu - ragu 15 responden (19.2\%), sedangkan yang menjawab sangat tidak setuju dan tidak setuju 2 responden (2.6\%). Diketahui nilai mean score sebesar 3.91 hasil tersebut pada kategori setuju karena berada pada rentang skala skala 3,4-4,2. dari hasil tersebut dapat diketahui, bahwa setelah responden menonton Film Jenderal Soedirman, responden merasakan adanya Nasionalisme di dalam dirinya.

Pada dimensi afektif yang berdasarkan jawaban responden tentang apakah Film Jenderal Soedirman sudah dibuat cukup baik, responden yang menjawab sangat setuju dan setuju sebanyak 70 responden (89.7\%), dan yang menjawab ragu - ragu sebanyak 8 responden $(10.3 \%)$, sedangkan yang menjawab sangat tidak setuju dan tidak setuju 0 responden. Diketahui nilai mean score sebesar 4.076 hasil tersebut berada pada kategori setuju karena berada pada rentang skala skala 3,4-4,2. Dari hasil tersebut dapat diketahui, bahwa Film Jenderal Soedirman sendiri menurut responden sudah dibuat sangat cukup baik.

Jawaban responden tentang Menurut Anda Pemeran Film Jenderal Soedirman sudah cukup baik, responden yang menjawab sangat setuju dan setuju sebanyak 55 responden $(70.5 \%)$, 
dan yang menjawab ragu - ragu sebanyak 21 responden $(26.9 \%)$, sedangkan yang menjawab sangat tidak setuju dan setuju sebanyak 2 responden (2.6\%). Diketahui Nilai mean score sebesar 3.846 hasil tersebut berada pada kategori setuju karena berada pada rentang skala skala 3,4-4,2. dari hasil tersebut dapat diketahui bahwa Menurut responden pemeran Film Jenderal Soedirman itu sudah cukup baik dalam memerankan perannya masing - masing.

Pada jawaban responden tentang Menurut Anda, Sutradara dan Tim Produksi sudah menyajikan Film Jendera Soedirman dengan Kualitas yang baik, responden yang menjawab sangat setuju dan setuju sebanyak 61 responden (78.2\%), dan yang menjawab ragu - ragu sebanyak 15 responden (19.2\%), sedangkan yang menjawab sangat tidak setuju dan tidak setuju sebanyak 2 responden (2.6\%). Diketahui Nilai mean score sebesar 3.923 hasil tersebut berada pada kategori setuju karena berada pada rentang skala skala 3,4-4,2, dari hasil tersebut dapat diketahui bahwa menurut responden Sutradara dan Tim Produksi dari Film Jenderal Soedirman sudah manyajikan Kualitas Film yang cukup baik.

Adapun jawaban responden tentang Apakah Film Jenderal Soedirman sudah menyajikan fakta secara tepat, responden yang menjawab sangat setuju dan setuju sebanyak 50 orang $(64.1 \%)$, dan yang menjawab ragu - ragu sebanyak 27 responden (34.6\%), sedangkan yang menjawab sangat tidak setuju dan tidak setuju sebanyak 1 responden (1.3\%). Diketahui nilai mean score sebesar 3.743 hasil tersebut berada pada kategori setuju karena berada pada rentang skala skala 3,4-4,2. Dari hasil tersebut dapat diketahui bahwa menurut responden Film Jenderal Soedirman sudah banyak menyajikan fakta secara tepat.

Pada jawaban responden tentang mengenai setelah anda menonton Film Jenderal Soedirman, apakah Anda tersentuh secara Emosional, responden yang menjawab setuju dan setuju sebanyak 50 responden (64.1\%), dan yang menjawab ragu - ragu 24 responden (30.8\%) sedangkan yang menjawab sangat tidak setuju dan tidak setuju sebanyak 4 responden
(5.1\%). Diketahui nilai mean score sebesar 3.693 hasil tersebut berada pada kategori setuju karena pada rentang skala skala 3,4-4,2. Dari hasil tersebut dapat diketahui bahwa responden setelah menonton Film Jenderal Soedirman emosional responden tersentuh.

Berdasarkan jawaban responden apakah Anda mendapatkan kepuasaan Emosional setelah menonton Film Jenderal Soedirman, responden yang menjawab sangat setuju dan setuju sebanyak 46 responden (59\%), dan yang menjawab ragu - ragu sebanyak 30 responden $(38.5 \%)$, sedangkan yang menjawab sangat tidak setuju dan tidak setuju sebanyak 2 responden (2.6\%). Diketahui nilai mean score sebesar 3.695 hasil tersebut berada pada ketegori setuju karena pada rentang skala skala 3,4-4,2 dari hasil tersebut dapat diketahui bahwa responden mendapatkan kepuasan emosional setelah menonton Film Jenderal Soedirman.

Tabel 2 Apakah Pengetahuan Anda Semakin Bertambah Setelah Menonton Film Jenderal Soedirman

\begin{tabular}{|ccc|}
\hline Pernyataan & Responden & Persentase \\
\hline Setuju dan Sangat Setuju & 65 & $83.3 \%$ \\
Ragu-Ragu & 13 & $16.7 \%$ \\
Tidak Setuju dan Sangat & - & - \\
Tidak Setuju & & $100 \%$ \\
Total & 78 & \\
\hline
\end{tabular}

Sumber: Hasil Penelitian, 2015

Jawaban responden tentang Apakah Pengetahuan Anda semakin bertambah setelah menonton Film Jenderal Soedirman, responden yang menjawab sangat setuju dan setuju sebanyak 65 responden $(83.3 \%)$, dan yang menjawab ragu - ragu sebanyak 13 responden $(16.7 \%)$, sedangkan yang menjawab sangat tidak setuju dan tidak setuju sebanyak 0 responden. Diketahui nilai mean score sebesar 4.038 hasil tersebut berada pada kategori setuju karena berada pada rentang skala skala 3,4 4,2. Dari hasil tersebut dapat diketahui bahwa setelah menonton Film Jenderal Soedirman, pengetahuan responden semakin meningkat atau bertambah. 
Tabel 3 Apakah Nilai Pesan Nasionalisme Yang Diberikan Oleh Film Jenderal Soedirman Sudah Positif

\begin{tabular}{ccc}
\hline Pernyataan & Responden & Persentase \\
\hline Setuju dan Sangat Setuju & 54 & $69.2 \%$ \\
Ragu-Ragu & 22 & $28.2 \%$ \\
Tidak Setuju dan Sangat & 2 & $2.6 \%$ \\
Tidak Setuju & & $100 \%$ \\
Total & 78 & \\
\hline
\end{tabular}

Sumber: Hasil Penelitian, 2015

Pada jawaban responden mengenai menurut Anda setelah Menonton Film Jenderal Soedirman Rasa Nasionalisme Anda semakin meningkat, responden yang menjawab sangat setuju dan setuju sebanyak 54 responden (69.2\%), dan yang menjawab ragu - ragu 22 responden (28.2\%), sedangkan yang menjawab sangat tidak setuju dan setuju sebanyak 2 responden (2.6\%). Diketahui nilai mean score sebesar 3.781 hasil tersebut berada pada ketegori setuju karena berada pada rentang skala skala 3,4-4,2. Dari hasil tersebut dapat diketahui bahwa Menurut Responden Rasa Nasionalisme responden semakin meningkat setelah Menonton Film Jenderal Soedirman.

Tabel 4 Apakah Anda Puas Dengan Kualitas Film Jenderal Soedirman

\begin{tabular}{ccc}
\hline Pernyataan & Responden & Persentase \\
\hline Setuju dan Sangat Setuju & 71 & $91.1 \%$ \\
Ragu-Ragu & 6 & $7.7 \%$ \\
Tidak Setuju dan Sangat & 1 & $1.3 \%$ \\
Tidak Setuju & & $100 \%$ \\
Total & 78 & \\
\hline
\end{tabular}

Sumber: Hasil Penelitian, 2015

Berdasarkan jawaban responden tentang apakah Nilai pesan Nasionalisme yang diberikan oleh Film Jenderal Soedirman sudah positif, responden yang menjawab sangat setuju dan tidak setuju sebanyak 71 responden (91,1\%), dan yang menjawab ragu - ragu sebanyak 6 responden (7.7\%), sedangkan yang menjawab sangat tidak setuju dan tidak setuju sebanyak 1 responden (1.3\%). Diketahui nilai mean score sebesar 4.145 hasil tersebut berada pada kategori setuju karena berada pada rentang skala skala 3,4-4,2. Dari hasil tersebut dapat diketahui bahwa menurut responden Nilai Nilai pesan Nasionalisme yang diberikan oleh Film Jenderal Soedirman sudah cukup Positif.

Jawaban responden tentang Apakah Anda puas dengan Kualitas Film Jenderal Soedirman, responden yang menjawab sangat setuju dan setuju sebanyak 64 responden (82\%), dan yang menjawab ragu - ragu sebanyak 12 responden (15.4\%), sedangkan yang menjawab sangat tidak setuju dan tidak setuju sebanyak 2 responden (2.6\%). Diketahui nilai mean score sebesar 3.909 hasil tersebut berada pada kategori setuju karena berada pada rentang skala 3,4 4,2. Dari hasil tersebut dapat diketahui bahwa menurut responden, responden merasa sangat puas dengan Kualitas yang disajikan oleh Film Jenderal Soedirman.

Dapat disimpulkan, bahwa mayoritas menjawab setuju. Hasil perhitungan rata-rata atau mean score sebesar 3.909 yang berada pada kategori setuju dengan rentang skala 3,4 $-4,2$. Dari hasil tersebut dapat diketahui bahwa menurut responden, responden merasa sangat puas dengan Kualitas yang disajikan oleh Film Jenderal Soedirman.

Penelitian ini memberikan gambaran sikap penonton mengenai Film Jenderal Soedirman. Fungsi dari film Jenderal Soedirman sendiri adalah memberikan hiburan dan juga terkandung fungsi informatif, edukatif, dan persuasif. Tanggapan ini dilihat dari tiga dimensi efek komunikasi massa yaitu efek Kognitif, Afektif, dan Behavioral. Adapun manfaat dari penelitian ini yaitu dapat menambah wawasan mengenai bagaimana media massa khususnya film.

Teori utama yang digunakan dalam penelitian ini, yaitu teori Sikap, ada dua pendekatan didalam mendefinisikan sikap, yaitu pendekatan yang pertama adalah memandang sikap sebagai kombinasi kondisi afektif, perilaku dan kognitif atau yang disebut sebagai pendekatan tricomponent. Pendekatan kedua ini muncul karena adanya ketidakpuasan mengenai kosistensi yang terjadi di antara tricomponent, sikap didefinisikan sebagai efek atau penulisan positif - negatif suatu objek (Azwar, 2011). 
Untuk memperkuat teori utama dalam penelitian ini,juga ditambahkan teoripendukung yaitu Efek Komunikasi Massa, yang terdiri dari 3 dimensi yaitu efek kognitif yang berkaitan dengan pengetahuan, keterampilan, dan informasi. Efek afektif mengenai perubahan, yang dirasakah khalayak, efek behavioral yang meliputi tingkah laku yang mendorong atau melakukan tindakan (Rakhmat, 2013).

Dari hasil penelitian ini dikatakan, bahwa Sikap penonton mengenai film jenderal Soedirman. Hasil dari dimensi kognitif sebesar 3.89 dan dimensi afektif sebesar 3.88 dapat dilihat dari penjelasan deskriptif statistik per dimensi dan dapat di simpulkan bahwa mayoritas responden setuju bahwa film Jenderal Soedirman mampu memberikan informasi, pemahaman baru dan memberikan perasaan emosional tentang sikap nasionalisme untuk mahasiswa-mahasiswi Universitas Prof. Dr. Moestopo Jakarta.

Berdasarkan hasil data SPSS di atas, diperoleh hasil mean perindikator dari kedua dimensi tersebut. Tanggapan yang paling besar dari mahasiwa dan mahasiswi ada pada dimensi Kognitif, menunjukkan overall mean score sebesar 3.89 yang berarti setuju. Sehingga dapat dikategorikan responden memberikan tanggapan positif pada dimensi kognitif yang lebih besar dibandingkan dengan dimensi Afektif.

Adapun dilihat dari hasil jawaban responden per-indikator, hasil terbesar ada pada dimensi Afektif sebesar 4.145, yaitu pada pernyataan "Apakah Nilai Pesan Nasionalisme yang diberikan oleh Film Jenderal Soedirman sudah positif'.

Dari dua dimensi di atas, dapat disimpulkan, bahwa mayoritas responden yang menyatakan bahwa sikap Nasionalisme muncul setelah Menonton Jenderal Soedirman. Jawaban responden dengan analisa mean atau ratarata menyatakan bahwa jawaban mereka pada rentang skala setuju, yaitu antara 3,4-4,2. Nilai analisa menunjukan bahwa rata - rata dari dua dimensi tersebut di jumlah dari dimensi kognitif dan afektif sebesar 3.88. Dapat dinyatakan dari hasil tersebut sebesar 3.88 dengan rentang skala 3.4- 4.2 yang berarti Setuju.
Dari ketiga efek ini, efek behavioral merupakan hasil dari efek kognitif dan afektif. Yaitu adanya perubahan sikap yang dialami oleh penonton baik secara pemahaman, pikiran, maupun secara perasaan emosional sehingga penonton merasakan bahwa, responden merasa dirinya tersentuh dan mengalami pengalaman emosional yang berhubungan dengan film atau tokoh Jenderal Soedirman.

Hal tersebut menjadi salah satu faktor dalam suksesnya suatu film dengan genre nasionalisme. Yaitu saat penonton merasakan adanya perasaan ikut serta dalam film tersebut dan menyadari kekurangan pemahaman dan sikap dalam menyikapi nasionalisme dan perasaan terikat pada bangsa tanah air.

Dapat disimpulkan bahwa, Film Jenderal Soedirman memberikan pengetahuan baru serta menunjang adanya perasaan emosional dalam merujuk sikap Nasionalisme Mahasiswa Universitas Prof. Dr. Moestopo (Beragama) Fakultas Ilmu Komunikasi untuk mencintai pahlawannya yang sudah berjuang dengan seluruh jiwa raganya dan tanpa adanya pamrih demi untuk mempertahankan eksistensi Negara Kesatuan Republik Indonesia dari Sabang sampai Meraoke dan dimana Nasionalisme bisa dilakukan dari wujud terkecil sampai dengan yang mengorbankan kesehatan diri bahkan kehidupan seseorang seperti yang dilakukan oleh Jenderal Soedirman.

Diawali dengan efek kognitif secara penalaran logika diikuti efek afektif yang berdasarkan pada emosi dan perasaan yang mampu menghasilkan perubahan pola pikir yang berdampak pada perubahan sikap, tingkah laku serta kebiasaan. Dimensi ini merupakan satu sistem yang saling berhubungan yang berujung pada sikap sebagai penentu sesuatu pengalaman telah dicerna sempurna oleh Mahasiswa-Mahasiswi Universitas Prof. Dr. Moestopo (Beragama).

\section{SIMPULAN}

Setelah melakukan penelitian yang berjudul sikap penonton terhadap Film nasionalisme: Studi deskriptif Mahasiswa Universitas Prof. Dr. Moestopo (Beragama) fakultas 
Ilmu Komunikasi Mengenai Film Jenderal Soedirman, peneliti dapat menyimpulkan berdasarkan hasil kuesioner yang telah disebarkan, diolah, dan dianalisa dari bab sebelumnya. Dilihat dari segi kognitif dapat disimpulkan bahwa mahasiswa Universitas Prof. Dr. Moestopo (Beragama) memberikan tanggapan yang positif mengenai Film Jenderal Soedirman. Responden setuju bahwa Film Jenderal Soedirman memberikan Pengetahuan baru dalam menyampaikan Pengetahuan Konteks Sejarah, dan unsur hiburannya yang mudah dipahami oleh kalangan lebih luas, tidak hanya bagi pemerhati Film Nasionalisme.

Adapun dari segi afektif dapat disimpulkan, bahwa responden memiliki tanggapan positif mengenai Film Jenderal Soedirman. Responden setuju bahwa Film Jenderal Soedirman memberikan perasaan emosional. Responden merasa kepuasaan emosional didapat setelah menonton Film Jenderal Soedirman dan pengetahuan bertambah setelah menonton Film tersebut. Rasa Nasionalisme Responden juga semakin meningkat setelah menonton film Jenderal Soedirman. Responden juga mengatakan bahwa nilai pesan Nasionalisme yang disampaikan film Jenderal Soedirman sudah positif, yang artinya film Jenderal Soedirman sudah menyajikan pesan nilai Nasionalisme yang baik. responden mayoritas mengatakan puas dengan kualitas film Jenderal Soedirman.

Bedasarkan dari dua Dimensi di atas, dapat disimpulkan, bahwa mayoritas Responden menyatakan bahwa Sikap Nasionalisme dan rasa Nasionalisme Responden muncul setelah Menonton Jenderal Soedirman dan setelah pengalaman yang mereka alami dari film Jenderal Soedirman dapat diasumsikan bahwa penonton sedikit demi sedikit akan berubah tingkah laku dan pandangan mereka tentang Sikap Nasionalisme. Hasil ini meliputi dari hasil perubahan Behavioral yang mencakup perubahan Sikap perilaku dan pola pikir dari Mahasiswa Universitas Prof. Dr. Moestopo (Beragama).

Film Jenderal Soedirman merupakan film Nasionalisme yang baik dan dapat mempengaruhi Sikap Nasionalisme Para penonton. Diharapkan adanya film - film Nasionalisme lainnya serta sampel yang lebih luas dan penelitian yang lebih mendalam. Saran berikutnya yaitu adanya penelitian lanjutan mengenai Sikap Nasionalisme terhadap film - film lain yang memiliki genre tentang tokoh Nasionalisme bangsa Indonesia dan melakukan pembahasan dan penelitian yang lebih mendalam tentang Studi Nasionalisme baik secara Teoritis maupun Implementatif.

\section{DAFTAR PUSTAKA}

Abidin, Z. (2017). Representasi nasionalisme dalam film Nagabonar Jadi 2: analisis semiotika Roland Barthes mengenai representasi nilainilai nasionalisme dalam film Nagabonar Jadi 2. Jurnal Politikom INdonesiana, 2(1), 42-61.

Akbar, K. M., Hanief, L., \& Alif, M. (2017). Semangat nasionalisme dalam film (analisis isi kuantitatif dalam film merah putih). ProTVF, 1(3), 125-138.

Alfaqi, M. Z. (2015). Memahami indonesia melalui prespektif nasionalisme, politik identitas, serta solidaritas Mifdal Zusron Alfaqi. Jurnal Pendidikan Pancasila Dan Kewarganegaraan, 28(2), 111-116. Diakses dari file:///C:/Users/ Pusdiklat32/Downloads/5451-4664-1-SM.pdf.

Amalia, R. (2015). Efek tayangan On The Spot terhadap pesan media massa bagi mahasiswa Ilmu Komunikasi Universitas Mulawarman. E-Journal Ilmu Komunikasi, 3(2), 30-42. Diakses dari http://ejournal.ilkom.fisipunmul.ac.id/site/wp-content/uploads/2015/04/ JURNAL (04-09-15-06-48-39).pdf.

Anshari, I. N. (2016). Sistem klasifi kasi dalam pemutaran film: studi kasus klasifi kasi film di Kinoki. Jurnal Ilmu Sosial Dan Ilmu Politik, 17(3), 220-235. https://doi.org/10.22146/ jsp.13087.

Ardian, M. (2013). Sikap masyarakat Surabaya terhadap program acara "PESBUKERS" Di ANTV. E-Komunikasi, 1(1), 1-11. Diakses dari https://media.neliti.com/media/ publications/80745-ID-none.pdf.

Ardianto, E., Komala, L., \& Karlinah, S. (2014). Komunikasi massa (revisi). Bandung: Simbiosa Rekatama Media.

Ayuningtyas, D. R., Suharso, R., \& Sodiq Ibnu. (2016). Perjuangan panglima besar Jenderal Soedirman pada masa revolusi fisik tahun 1945-1950. Journal of Indonesian History, $5(1), 10-17$.

Azwar, S. (2011). Sikap manusia teori dan pengukurannya (2nd ed.). Yogyakarta: Pustaka 
Pelajar.

Baran, S. J. (2011). Pengantar komunikasi massa (6th ed.). Jakarta: Salemba Humanika.

Djaya, A. B. (2015). Jawaban atas kritik terhadap film Jenderal Soedirman. Diakses dari http:// beritagar.id/artikel/seni-hiburan/jawaban-ataskritik-terhadap-film-jenderal-soedirman.

Dory. (2015). Film Jenderal Soedirman. Diakses dari http://www.movie.co.id/jenderal-soedirman/.

Febtriko, A., \& Puspitasari, I. (2018). Mengukur kreativitas dan kualitas pemograman pada siswa SMK kota Pekanbaru Jurusan Teknik Komputer Jaringan dengan simulasi robot. Rabi : Jurnal Teknologi Dan Sistem Informasi Univrab, 3(1), 1-9. https://doi.org/10.36341/ rabit.v3i1.419.

Hens, H. (2015). Data penonton 10 September 2015, gangster-Soedirman masih berjaya. https://www.fimela.com/news-entertainment/ $\mathrm{read} / 2314303 /$ data-penonton-10-september2015-gangster-soedirman-masih-berjaya.

Mubasyaroh. (2014). Film sebagai media dakwah (sebuah tawaran alternatif media dakwah kontemporer). AT-TABSYIR, Jurnal Komunikasi Penyiaran Islam, 2(2), 1-16.

Natalia, L. (2011). 9 Film bertema nasionalisme untuk menyambut hari kemerdekaan. Diakses dari http://www.jagatreview.com/2011/08/9film-bertema-nasionalisme-untuk-menyambuthari-kemerdekaan/.

Pakpahan, D. R. (2017). Pengaruh pengetahuan dan sikap terhadap perilaku masyarakat pada Bank Syariah di wilayah kelurahan Sei Sikambing d. At-Tawassuth, 3(3), 345-367.

Pradana, M., \& Reventiary, A. (2016). Pengaruh atribut produk terhadap keputusan pembelian sepatu merek Customade (studi di merek dagang Customade Indonesia). Jurnal Manajemen, 6(1), 1-10. https://doi.org/10.26460/ jm.v6i1.196.

Rakhmat, J. (2013). Psikologi komunikasi. Bandung: Remaja Rosdakarya.

Sadewa, B. (2015). Ini film pertama di dunia, berdurasi pendek. Diakses dari http:// infofilm21.com/ini-film-pertama-di-duniaberdurasi-pendek/

Sutorini, M. P., Alif, M., \& Sarwani, S. (2019). Semiotika gender dalam film Brave. ProTVF, 3(1), 101-112. https://doi.org/10.24198/ptvf. v3i1.21246.

Trianton, T. (2013). Film sebagai media belajar (1st ed.). Yogyakarta: Graha Ilmu. 